\title{
Hurricane Igor Impacts at Northern Latitudes: Factors Influencing Tree Fall in an Urban Setting
}

\author{
Yolanda F. Wiersma, Troy L. Davis, Elizabeth C. Eberendu, lan Gidge, Maria Jewison, Hiliary C. \\ Martin, Kaylah C. Parsons, Heidi Patterson, and Ashley Quirke
}

\begin{abstract}
Hurricane Igor was a Category 1 hurricane when it passed the island of Newfoundland, Canada, causing extensive damage. Hurricanes are uncommon at northern latitudes, and boreal species are not adapted to hurricane-force winds. Moreover, much of the storm damage was in the urban area of the City of St. John's, where there are also numerous non-native trees. This research tested whether there were attributes of trees (e.g., height, diameter at breast height, slenderness, species, age, or distance to nearest tree) that may have influenced whether a tree fell or was left standing. The study authors sampled 70 trees and found that DBH was a significant predictor of tree fall (snapping or uprooting). Conifers were no more or less likely to fall in the storm than deciduous trees, nor were native trees more or less susceptible to wind damage than non-natives. These results suggest that for a boreal, urban ecosystem, there are no target species available that could be planted strategically to minimize risk of tree fall in a major wind event. Thus, to minimize storm damage to humanbuilt infrastructure in regions where hurricanes are rare, the best strategy would be to avoid having large trees located in close proximity to infrastructure.

Key Words. Abies balsamea; Acer platanoides; Acer pseudoplatanus; Betula papyrifera; Boreal Forest; Hurricane; Picea mariana; Tilia americana; Tree Damage; Urban Forest; Wind Damage.
\end{abstract}

Severe wind storms, in particular hurricanes, can have dramatic impacts on urban forests and trees. Although disturbance is a natural ecological phenomenon, wind disturbance of trees in urban areas often impacts built infrastructure (e.g., buildings, power lines) and can cause temporary road closures as well as a reduction of landscape aesthetics. Tropical and sub-tropical regions are exposed to hurricanes on a relatively frequent basis, and research on the susceptibility of trees to hurricane damage in these areas is well studied (e.g., Lugo et al. 1983; Gresham et al. 1991; Walker 1991; Zimmerman et al. 1994; Asner and Goldstein 1997; Weaver 1999; Boose et al. 2004; Canham et al. 2010). However, most of this research is outside of urban areas. Research on the impacts of hurricanes on trees in urban areas within tropical and sub-tropical regions is limited to a few studies in San Juan, Puerto Rico (Francis 2000; Boose et al. 2004; Duryea et al. 2007a) and cities in Florida, U.S. (Duryea et al. 1996; Duryea et al. 2007a; Duryea et al. 2007b). There is even less research on the impacts of hurricanes in more northern latitudes, in part due to the infrequency of hurricane-force storms in these areas. Research in northern forests has focused more on wind damage generally (e.g., Webb 1989; Peterson 2000; Peterson 2007; Ulanova 2000; Kane 2008; Zeng et al. 2009) and not on hurricanes specifically. Work on hurricane effects on trees in temperate and more northerly latitudes is limited; there has been some work following Hurricane Juan in Nova Scotia, Canada (Cameron 2004; Burley et al. 2008), and research to develop historical reconstructions of the 1938 New England hurricane (Boose et al. 1994; Busby et al. 2009). Moreover, most of the research on wind damage in more northerly latitudes is focused away from urban areas. The last hurricane event to affect an urban area in Atlantic Canada was Hurricane Juan, which struck Nova Scotia in 2003. The provincial Department of Natural Resources investigated factors that might have made commercial forest stands more susceptible to damage (reported in Cameron 2004); other research following Hurricane Juan has focused on mitigating damage to power lines (Kochanoff 2004) and forest recovery/restoration two years after the hurricane (Burley et al. 2008).

Hurricane Igor presented a unique opportunity to study the impacts of a hurricane in an urban setting located within a boreal ecozone. On September 21, 2010, Hurricane Igor passed very close to the island of Newfoundland, on the northeast coast of Canada (Figure 1). With winds of 120 to $130 \mathrm{~km} / \mathrm{h}$, and gusting from 150 to $165 \mathrm{~km} / \mathrm{h}$, this Category 1 hurricane was a once in 75-100 year event for the region (Environment Canada 2010; Pasch and Kimberlain 2011; World Meteorological Organization 2011). The storm caused more than CAD $\$ 200$ million in damage, and included the toppling of many trees as well as bridge and road washouts and damage to buildings (Pasch and Kimberlain 2011). Storm records for the greater St. John's urban area, consisting of the City of St. John's and surrounding municipalities, showed that the area was hit rather hard, with wind gusts of $137 \mathrm{~km} / \mathrm{h}$ recorded at the airport meteorological station, with sustained speeds of $92 \mathrm{~km} / \mathrm{h}$ over 10 minute intervals (Environment Canada 2010). The high winds were preceded by $120-134 \mathrm{~mm}$ of rainfall in the St. John's area over an interval of a few hours (Environment Canada 2010; Pasch and Kimberlain 2011). It was estimated that approximately 1200 public trees within the city limits (excluding surrounding 
smaller municipalities) were felled or required significant pruning or removal following the storm (Brian Head, Acting Manager Streets and Parks Division, City of St. John's, pers. comm.).

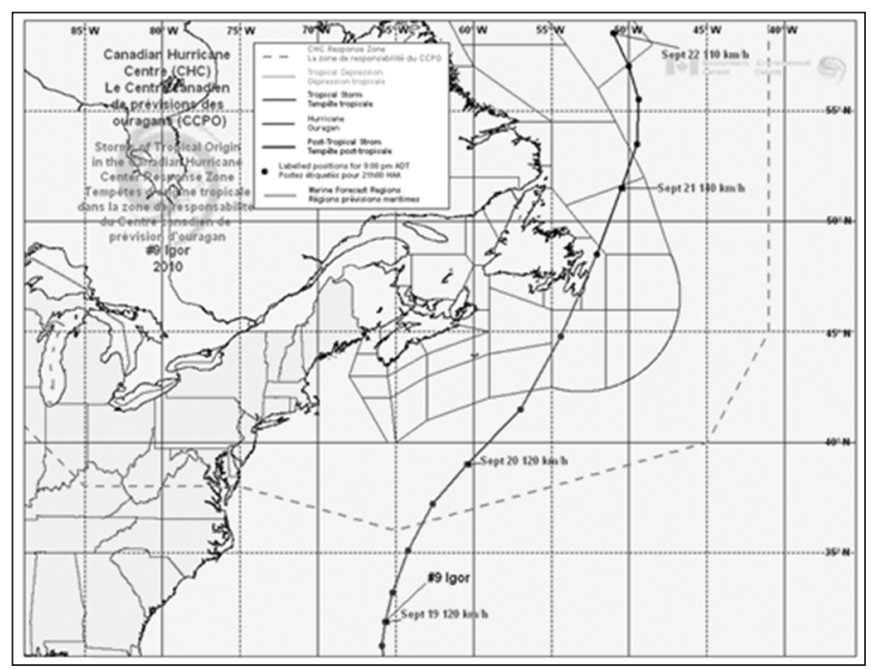

Figure 1. Hurricane Igor storm track, September 19-21, 2010. Source: Environment Canada.

The island of Newfoundland is located within the Boreal Shield Ecozone of Canada (Wiken et al. 1996). The boreal forest is dominated by coniferous softwood trees, such as black spruce [Picea mariana (Mill.) B.S.P.] and balsam fir [Abies balsamea (L.) Mill.], as well as occasional hardwoods such as white birch (Betula papyrifera Marsh). The greater St. John's area lies within the provincial Maritime Barrens ecoregion (Damman 1983). Although described as a "barrens," the ecoregion has many pockets of forest that are dominated by balsam fir. In the urban region, planted non-natives include sycamore maple (Acer pseudoplatanus L.), Norway maple (Acer platanoides L.), and linden (Tilia americana L.) (Fry et al. 2008) as well as numerous other ornamentals and exotics.

Given the rarity of a hurricane in an urban region within a boreal setting, researchers set out to determine whether there were factors that influenced which trees in the greater St. John's area were damaged by Hurricane Igor. Research in the tropics and sub-tropics on hurricane damage in urban areas has shown that windthrow causes two types of damage: uprooting or stem (i.e., snapping of the trunk). This damage is related to tree species (Francis 2000; Duryea et al. 2007a; Duryea et al.2007b), tree size, measured by both height and diameter at breast height (Duryea et al. 2007a; Duryea et al.2007b), the degree to which tress grew in clusters (Duryea et al. 2007a; Duryea et al.2007b), soil saturation (Fan and Su 2008), and soil type (Francis 2000). The variation in uprooting and stem breakage (collectively referred to as "stem failure") by species is believed to be related to wood strength (Francis 2000; Duryea et al. 2007a; Duryea et al.2007b), with trees with denser wood less likely to snap or be uprooted, although this was not observed in all hurricanes in Florida (Duryea et al. 2007a; Duryea et al.2007b). Direct tests of wood strength have been shown to be correlated with stem failure in Hawaii, U.S. (Asner and Goldstein 1997). Asner and Goldstein (1997) also showed that native trees were more likely to remain stand- ing, but when they fell, were more likely to be uprooted than snapped. On the other hand, non-native trees were more likely to be snapped than uprooted and had a higher percentage of damage overall (Asner and Goldstein 1997). This is similar to the pattern observed in Dade County, Florida, following Hurricane Andrew (Duryea et al. 1996) and for tropical species across Florida following Hurricanes Jeanne and Charley (Duryea et al. 2007b). However, Duryea et al. (2007a) did not see a difference in damage rates between native and non-native coastal plain tree species across Florida following Hurricanes Erin, Opal, Ivan, Dennis, Charley, Frances, and Jeanne or for tropical tree species following Hurricane Georges (Duryea et al. 2007b). The variation in the tree properties and damage rates between different hurricanes in urban areas across the same study area observed by Duryea et al. (2007a) and Duryea et al. (2007b) suggests that the properties of the storm itself appear to influence patterns of tree damage.

Research on tree properties and hurricane damage in non-urban tropical and sub-tropical forests shows that damage appears to be a factor of species (Gresham et al. 1991; Zimmerman et al. 1994), wood density (Zimmerman et al. 1994), DBH (Lugo et al. 1983; Gresham et al. 1991; Walker 1991; Zimmerman et al. 1994; Kane 2008), and location [e.g., distance from coast, topographic position, stand density (Lugo et al. 1983), and aspect (Lugo et al. 1983; Walker 1991)]. A study of stand-level variation in damage in response to Hurrican Juan (the most recent hurricane to hit Atlantic Canada prior to Igor) showed that stand density (those that had undergone pre-commercial thinning) and average slenderness of trees in the stand were the only significant factors (Cameron 2004). Analyses of temperate and boreal forest response to non-hurricane windstorm events (including thunderstorms and tornados) suggest that damage is explained in part by tree size (Peterson 2007; Valinger and Fridman 2011), stand composition and age (Ulanova 2000), wood strength (Peterson 2007), soil properties (Ulanova 2000), and amount of thinning (Kane 2008). However, as with patterns of hurricane damage, specific damage patterns are more complex (Webb 1989; Boose et al. 1994; Kane 2008). Much of the research on wind damage in boreal forests has focused on patterns at stand and landscape levels (e.g., Boose et al. 1994; Ulanova 2000; Boose et al. 2001; Zeng et al. 2009; Valinger and Fridman 2011) and has made use of simulation models of wind storms (e.g., Achim et al. 2005; Zeng et al. 2009; Zeng et al. 2010). Experimental tree-pulling of boreal species has suggested that DBH and height (Peltola et al. 2000) and soil properties (Elie and Ruel 2005) are important factors in determining susceptibility to blowdown in a wind event.

It was hypothesized that for the current urban boreal study area, factors likely to influence tree fall (either uprooting or snapping) were species, age, size (height and $\mathrm{DBH}$ ), slenderness, and location (within dense stands or in more open, wind-exposed areas). Specifically, the study authors predicted that native species would be less likely to be damaged, even though trees in this part of the world have not had the opportunity to evolve with hurricane exposure. Most of the native trees are conifers, and hurricane research in the southeastern United States and elsewhere has not shown clear trends of higher susceptibility of conifers to hurricane damage, despite their less-dense wood (Gresham et al 1991; Everham and Brokaw 1996; Duryea et al. 2007a). Nonnative species in the urban St. John's area have a tendency to be Sycamore maple, Norway maple, and linden, which are also not native to hurricane-prone areas, and thus are not expected to 
have a high natural resistance to hurricanes. Moreover, St. John's routinely experiences high winds (but not hurricane events), and so native species may be expected to have evolved some resistance to wind disturbance. At the time the hurricane struck, the deciduous trees were still in full-leaf, and researchers did not expect crown streamlining to have a major effect between conifers and deciduous species. Overall, the authors expected to see differences between native and non-native species as well as between conifers and non-conifers. Across species, larger trees (both in terms of height and $\mathrm{DBH}$ ) and those that were less slender (lower height to DBH ratio) were expected to be more susceptible to falling or snapping. Age and condition were also expected to be a factor with older trees and those with rot or recent spanworm damage (Fry et al. 2008) being more susceptible.

\section{METHODS}

\section{Study Area}

The study area included the cities of St. John's and Mount Pearl, and the town of Paradise, on the Avalon Peninsula, island of Newfoundland, Canada (Figure 2). The population of this region is approximately 190,000 (Statistics Canada 2011 census). While the downtown city of St. John's is row housing, and there are apartment dwellings throughout the urban areas, most of the sample sites fell within areas with suburban development and single-family dwellings, in nearby public parks, or in small tracts of forest in close proximity to subdivisions. Locations of all sample sites are shown in Figure 3; locations were sampled with a handheld GPS unit (Garmin 76map).

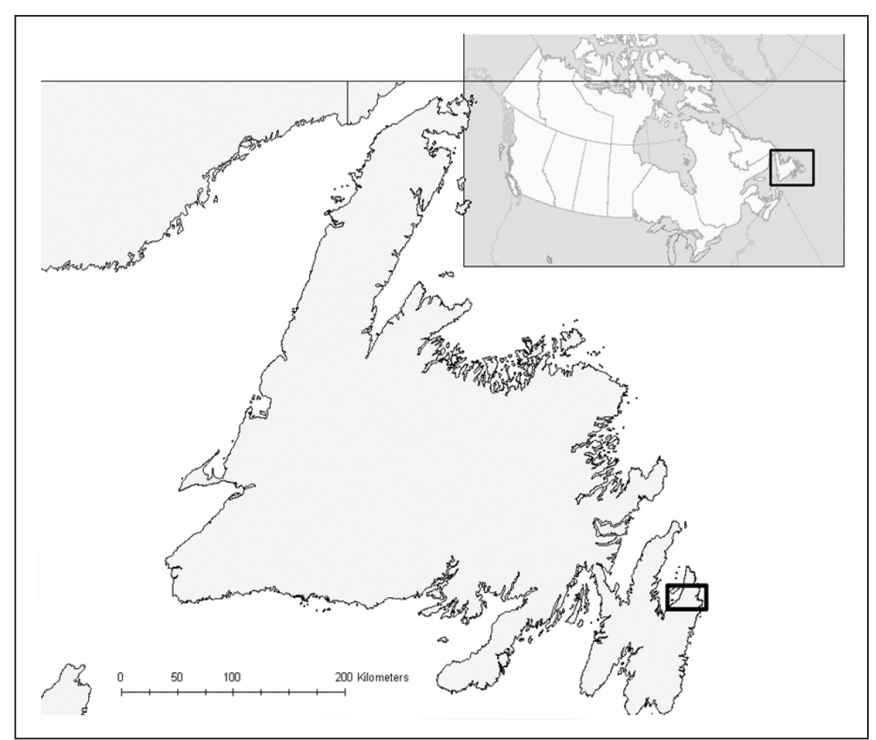

Figure 2. Map of the study area (dark rectangle) on the northeast Avalon Peninsula, on the island of Newfoundland, Canada. The inset map shows the location of Newfoundland relative to the rest of Canada.

\section{Tree Sampling}

Tree sampling was carried out on the weekend following the storm (September 25-26, 2010); researchers randomly selected sites to visit in the greater St. John's area. There was no attempt to control for microsite variation (e.g., slope, topographic position) because the study authors were interested in how trees vary in their response by species across the larger area of impact. At each site, data were recorded on a randomly selected fallen (uprooted or snapped) tree, as well as on the nearest standing tree. The assumption was that trees in close proximity to each other would have been exposed to the same localized wind patterns. The authors were not able to control for sampling adjacent trees in the same wind direction. Where there was a group of trees that had fallen together and evidence that this was due to root interlocking (often part of the root mass was exposed) or one tree knocking down a neighbour, data were measured from the nearest tree still standing. Thus the pair-wise analysis of a single fallen and single adjacent standing tree was used to test whether tree properties of species, height, DBH, slenderness, and age contributed to the propensity for a tree to be uprooted or snapped. Data collected included species [Ryan (1978) and Farrar (1995) were used for reference], location (as sampled with a GPS unit), height/length, diameter, and distance to nearest standing tree. Once data were entered, the slenderness (ratio of height to diameter was calculated). The same data were recorded for standing trees. In addition, for the trees that were uprooted, root depth and diameter were measured. Any notes on condition (evidence of past spanworm damage, core rot, etc.) were also noted for both standing and downed trees.

Following compilation of field data, all sites were revisited to verify species identification and to take a tree core for aging. All cores were counted with a $10 \times$ hand lens by a single member of the team. Cores were recounted (blind) by a second researcher. In the event of a difference $>5$ years between age estimates by the two researchers, the second researcher re-counted a second time (again blind); and if second re-count was within $<5$ years of first re-count, then the mean of the two re-counts of the second researcher (who had more experience) were taken.

\section{Statistical Analysis}

Researchers carried out all statistical analysis using MINITAB (v. 15). Trees were categorized into native/non-native classes and into coniferous/deciduous in two separate analyses. Binary logistic regression was carried out to test for differences in category (native/non-native or coniferous/deciduous) and in properties of height, $\mathrm{DBH}$, slenderness, age, and distance to nearest standing tree. Two sets of models were run within each analysis: one including tree height and DBH but not slenderness, and the other with slenderness included. This was to account for the fact that many species do not show a high degree of variation in slenderness (Kane 2008). Post-hoc goodnessof-fit tests (Pearson $\chi^{2}$ ) were applied and measures of association tested. A second set of tests tested against age combined with a quadratic term for age to test whether the youngest and oldest trees had a different response than mid-aged trees.

\section{RESULTS}

A total of 35 sites were visited, for a total of 70 trees surveyed (35 standing and 35 downed). Dominant species were balsam fir (24 trees; 13 of which were uprooted or snapped) and black spruce (13 trees; 7 of which were uprooted or snapped). Of the 35 uprooted/snapped trees, 24 were conifers, and 28 were native species. However, 23 of the 35 undamaged trees 


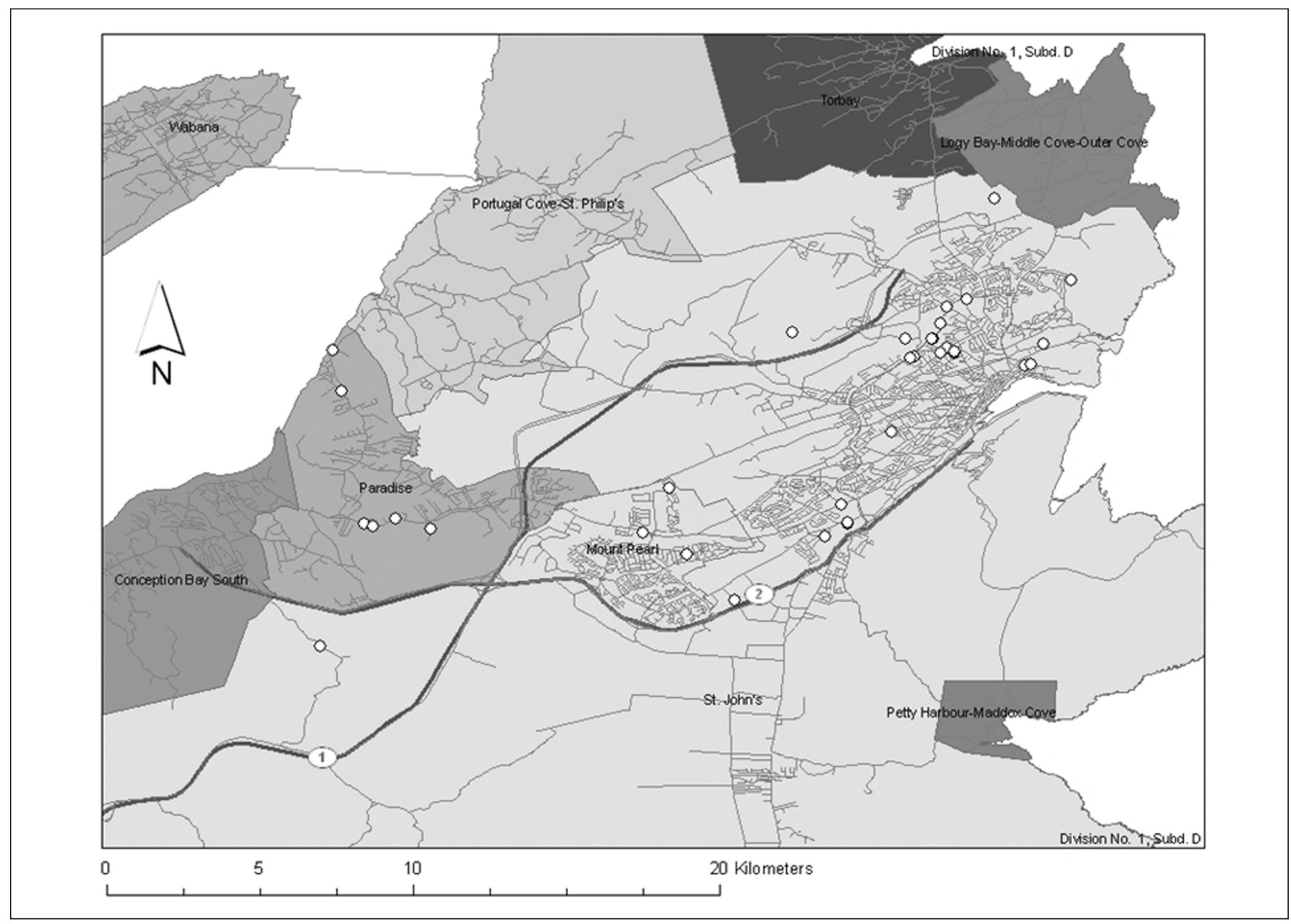

Figure 3. The greater St. John's area with sites of sampling locations (white dots) and major streets (black lines) indicated.

were also conifers, and 25 were native species. Binary logistic regression confirmed that neither category (coniferous/ deciduous or native/non-native) was a significant predictor of whether trees were left standing or were uprooted/snapped.

The properties of the standing versus downed trees are summarized in Table 1. The results of the binary logistic regression showed that DBH was a significant predictor in explaining the difference between uprooted/snapped trees and those left standing (coefficient $=0.258 \pm 0.12$ s.e., $p=0.031$ when the analysis categorized trees as coniferous/deciduous, and coefficient $=0.254 \pm 0.12$ s.e., $p=0.44$ when the analysis categorized trees as native/non-native), but only when slenderness was excluded from the model. When slenderness was included, DBH was no longer significant in either analysis, and slenderness was negatively related to tree fall in the analysis of coniferous/ deciduous trees (Coefficient $=-45.28 \pm 26.5$ s.e.) although this was not highly significant $(p=0.09)$. When slenderness was included in the analysis of native/non-native trees it was highly non-significant $(p=0.25)$. Height, distance to nearest standing tree, and age (neither as a univariate or quadratic term) were not significant predictors. The mean age and height of standing species was slightly (but not significantly) higher (Table 1).

Of the 35 damaged trees, 10 were snapped and 25 were uprooted. There was no significant correlation between the type of damage (snapping or uprooting) and a tree's classification as native/non-native or deciduous/coniferous. Uprooted trees had an average root depth of $219.4 \mathrm{~cm}( \pm 135.8 \mathrm{~cm}$ s.e. $)$ and an average root diameter of $49.8 \mathrm{~cm}( \pm 29.5 \mathrm{~cm}$ s.e. $)$.

Table 1. Summary attributes of fallen $(n=35)$ versus downed $(n=35)$ trees sampled in the greater St. John's area (Newfoundland, Canada) following Hurricane Igor. Values reported below are mean ( $(\mathrm{SD})$.

\begin{tabular}{lll}
\hline Attribute & Fallen trees & Standing trees \\
\hline Height $(\mathrm{m})$ & $8.4( \pm 3.5)$ & $10.5( \pm 11.3)$ \\
DBH $(\mathrm{cm})$ & $25.5( \pm 11.4)$ & $16.0( \pm 8.7)$ \\
Slenderness ratio (height:diameter) & $0.36( \pm 0.12)$ & $0.67( \pm 0.53)$ \\
Age & $24.5( \pm 10)$ & $33.6( \pm 17)$ \\
Distance to nearest standing tree $(\mathrm{m})$ & $3.6( \pm 2.7)$ & $3.8( \pm 3.1)$ \\
Percent conifers $(\%)$ & 68.5 & 65.7 \\
Percent native species $(\%)$ & 80.0 & 71.4 \\
\hline
\end{tabular}

\section{DISCUSSION}

The trend for trees with larger DBH to be more susceptible to falling in hurricane force winds is consistent with patterns observed in the tropics and subtropics (Lugo et al. 1983; Gresham et al. 1991; Walker 1991; Zimmerman et al. 1994; Duryea et al. 2007a; Duryea et al. 2007b), as well as temperate regions fol- 
lowing extreme wind events (Kane 2008). The influence of slenderness in affecting damage is consistent with analysis following Hurricane Juan, which was the most recent hurricane to hit at northern latitudes (albeit in a more temperate/Acadian forest zone). Here, slenderness and stand density were found to be the only significant predictors of stand damage (Cameron 2004).

Unlike some studies in the tropics that showed different damage patterns for native/non-native species in some storms (Asner and Goldstein 1997; Duryea et al. 2007a; Duryea et al. 2007b), tree category did not appear to affect susceptibility to tree fall. Other factors that have been shown to influence tree fall in the topics include the degree to which trees are clumped (Duryea et al. 2007a; Duryea et al. 2007b). In the current study, researchers measured the distance from each fallen tree to the nearest standing tree, but this was not a significant predictor. This metric is not necessarily a useful predictor of spatial patterns of clumping, and the pair-wise sampling design employed did not enable individuals to examine larger scale patterns of tree fall across the greater St. John's area as a function of spatial patterns of tree aggregations.

Francis (2000) and Duryea et al. (2007a; 2007b) suggested the soil and rooting properties were significant predictors of tree fall in tropical and subtropical urban areas. While soil types are not homogenous across the current study area (Heringa 1981), soils in the province are generally very thin and rocky. Root profiles of those trees that were uprooted were mostly wide diameter and shallow depth. The authors did not have root profiles for the trees that snapped or remained standing, and were unable to assess whether these were different from those trees that were uprooted. The high amount of rainfall immediately preceding the hurricane-force winds, coupled with the thin soil and poor drainage of the entire island, resulted in highly saturated soils during the storm. Thus, shallow-rooted trees may have been more susceptible to blow down due to weakened soil cohesion in saturated conditions. However, uprooting was not related to species, so if root profiles are species-specific, then this hypothesis is likely not supported. Nonetheless, if localized soil patterns are such that they contribute to shallow rooting, then this may have contributed to patterns of tree fall. Because of the nature of the pair-wise sampling, the authors were unable to statistically test this hypothesis. An analysis of tree fall in high wind events in Minnesota (Webb 1989) showed that high rainfall/wet soil confounded results when looking for patterns in tree properties. Similarly, Everham and Brokaw (1996), in a review of a large suite of papers on wind damage, showed that in many studies, rainfall amounts influenced damage rates, and Fan and $\mathrm{Su}$ (2008) demonstrated how soil saturation affects shear strength of soils in Taiwan.

Whether a tree was a conifer or deciduous did not affect whether it was damaged, or if damaged, whether it was snapped or uprooted. Hurricane Igor hit while the leaves were still on the trees. If the storm had been later in the season (i.e., postleaf drop), then different results may have been expected (Kane 2008). Many studies (see summary in Everham and Brokaw 1996) have shown no difference in damage rates between deciduous and coniferous trees, and coniferous trees in Nova Scotia were not more resilient to uprooting following Hurricane Juan (Cameron 2004). Moreover, whether a tree was native to the island of Newfoundland or not did not affect whether it was damaged, or if damaged, if it was uprooted or snapped. This is consistent with some (but not all) observations of native/ non-native species in Florida across different hurricane events
(Duryea et al. 2007a; Duryea et al. 2007b), but is inconsistent with observations from Hawaii (Asner and Goldstein 1997).

Overall, it appears that at very localized scales (i.e., between adjacent trees subjected to the same wind patterns), those that were larger in diameter (but not height) were more likely to be uprooted or snapped by Hurricane Igor, and that this pattern did not differ between coniferous and deciduous species or between native and non-native species. Across the region, high rainfall immediately preceding the storm saturated the soils, which may have been a contributing factor in uprooting events (Everham and Brokaw 1996; Fan and Su 2008).

\section{CONCLUSION}

Hurricane Igor was a rare Category 1 hurricane event for the island of Newfoundland. While much larger and more frequent storms are not unexpected at more southern latitudes, trees in more northern latitudes have not had a chance to evolve in response to hurricane-force winds. The rarity of the storm afforded a unique opportunity to assess factors affecting tree fall in an urban setting situated within a boreal ecozone. Consistent with the dominant pattern across a range of studies from the tropics, subtropics, and temperate zones the size of trees (measured as DBH) was the best predictor of whether an individual tree was snapped or uprooted.

Given that there were no clear patterns of different species being more or less susceptible to snapping/uprooting, coupled with the rarity of the storm, recommendations for planting to avoid wind damage [such as those provided by Duryea et al. (2007a) and Duryea et al. (2007b)] cannot be made at this time. The intense rain and soil saturation was likely a major factor in the amount of damage, and those trees with more shallow roots simply fell over in the wet, shallow soils. Due to the island's location in the North Atlantic, any future hurricane events are likely to be preceded by high rainfall. Thus the only planting strategy that might avoid damage to infrastructure is to make sure large trees are not adjacent to infrastructure (e.g., buildings, power lines), especially when those trees are on particularly shallow, rocky, or poorly drained soils. However, damage to trees and forest ecosystems will likely be unavoidable in future hurricane events in Newfoundland.

Acknowledgments. Thanks to Linda Morrissey and Gary Collins for timely assistance with equipment. Troy L. Davis thanks Dave Schneider for statistical advice. Ashley Quirke was funded by a Memorial University Career Employment Placement granted to Yolanda F. Wiersma. This project was also supported through a Natural Science and Engineering Research Council Discovery Grant to Yolanda F. Wiersma.

\section{LITERATURE CITED}

Achim, A., J.-C. Ruel, B.A. Gardiner, G. Laflamme, and S. Meunier. 2005. Modelling the vulnerability of balsam fir forests to wind damage. Forest Ecology and Management 204:35-50.

Asner, G.P., and G. Goldstein. 1997. Correlating stem biomechanical properties of Hawaiian canopy trees with hurricane wind damage. Biotropica 29:145-150.

Boose, E.R., D.R. Foster, and M. Fluet. 1994. Hurricane impacts to tropical and temperate forest landscapes. Ecological Monographs 64:369-400.

Boose, E.R., K.E. Chamberlin, D.R. Foster. 2001. Landscape and regional impacts of hurricanes in New England. Ecological Monographs $71: 27-48$. 
Boose, E.R., M.I. Serrano, and D.R. Foster. 2004. Landscape and regional impacts of hurricanes in Puerto Rico. Ecological Monographs 74:335-352.

Burley, S. S.L. Robinson, and J.T. Lundholm. 2008. Post-hurricane vegetation recovery in an urban forest. Landscape and Urban Planning 85:111-122.

Busby, P.E., C.D. Canham, G. Motzkin, and D.R. Foster. 2009. Forest response to chronic hurricane disturbance in coastal New England. Journal of Vegetation Science 20:487-497.

Cameron, D. 2004. Learning forestry lessons from Hurricane Juan experience. Forestry Chronicle 80:656.

Canham, C.D., J. Thompson, J.K. Zimmerman, and M. Uriarte. 2010. Variation in susceptibility to hurricane damage as a function of storm intensity in Puerto Rican tree species. Biotropica 42:87-94.

Damman, A.W.H. 1983. An ecological subdivision of the island of Newfoundland: Biogeography and ecology of the island of Newfoundland. pp. 163-206. Government of Newfoundland and Labrador.

Duryea, M.L., G.M. Blakeslee, W.G. Hubbard, and R.A. Vasquez. 1996. Wind and trees: a survey of homeowners after Hurricane Andrew. Journal of Arboriculture 22:44-50.

Duryea, M.L., E. Kampf, and R.C. Littell. 2007a. Hurricanes and the urban forest: I. Effects on Southeastern United States coastal plain tree species. Arboriculture \& Urban Forestry 33:83-97.

Duryea, M.L., E. Kampf, R.C. Littell, and C.D. Rodríguez-Pedraza. 2007b. Hurricanes and the urban forest: II. Effects on tropical and subtropical tree species. Arboriculture \& Urban Forestry 33:98-112.

Elie, J.-G., and J.-C. Ruel. 2005. Windthrow hazard modelling in boreal forests of black spruce and jack pine. Canadian Journal of Forest Research 35:2655-2663.

Environment Canada. 2010. Tropical cyclone season summary. Accessed 10/06/2011. <www.ec.gc.ca/ouragans-hurricanes/default. asp?lang=En\&n=2A6E3A33-1\#X-2011041910454815>

Everham, E.M. III, and N.V.L. Brokaw. 1996. Forest damage and recovery from catastrophic wind. Botanical Review 62:113-185.

Fan, C.-C., and C.-F. Su. 2008. Role of roots in the shear strength of rootreinforced soils with high moisture content. Ecological Engineering 33:157-166.

Farrar, J.L. 1995. Trees in Canada. Fitzhenry \& Whiteside Ltd., Markham, Ontario, Canada.

Francis, J.K. 2000. Comparison of hurricane damage to several species of urban trees in San Juan, Puerto Rico. Journal of Arboriculture 26:189-197.

Fry, H.R.C., K.L. Ryall, P.L. Dixon, and D.T. Quiring. 2008. Suppression of Ennomos subsignaria (Lepidoptera: Geometridae) on Acer pseudoplatanus (Aceraceae) in an urban forest with bole-implanted acephate. Journal of Economic Entomology 101:822-828.

Gresham, C.A., T.M. Williams, and D.J. Lipscomb. 1991. Hurricane Hugo wind damage to southeastern U.S. coastal forest tree species. Biotropica 23:420-426.

Heringa, P.K. 1981. Soils of the Avalon Peninsula, Newfoundland. Report No. 3. Land Resource Research Institute Publication 113, Research Branch Agriculture Canada.

Kane, B. 2008. Tree failure following a windstorm in Brewster, Massachusetts, USA. Urban Forestry \& Urban Greening 7:15-23.

Kochanoff, S. 2004. Trees versus power lines: Priorities and implications in Nova Scotia. Plan Canada 44:43-45.
Lugo, A.E., M. Applefield, D.J. Pool, and R.B. McDonald. 1983. The impact of Hurricane David on the forests of Dominica. Canadian Journal of Forest Research 13:201-211.

Pasch, R.J., and T.B. Kimberlain. 2011. Tropical Cyclone Report: Hurricane Igor (AL112010). National Hurricane Center, NOAA. Accessed 06/21/2011. <www.nhc.noaa.gov/pdf/TCR-AL112010_Igor.pdf>

Peltola, H., S, Kellomäki, A. Hassinen, and M. Granander. 2000. Mechanical stability of Scots pine, Norway spruce and birch: an analysis of tree-pulling experiments in Finland. Forest Ecology and Management 135:143-153.

Peterson, C.J. 2000. Damage and recovery of tree species after two different tornadoes in the same old growth forest: a comparison of infrequent wind disturbances. Forest Ecology and Management 135:237-252.

Peterson, C.J. 2007. Consistent influence of tree diameter and species on damage in nine eastern North America tornado blowdowns. Forest Ecology and Management 250:96-108.

Ryan, A.G. 1978. Native trees and shrubs of Newfoundland and Labrador. Parks Division, Department of Tourism, Government of Newfoundland and Labrador, St. John's NL.

Statistics Canada. 2011. Population and dwelling counts, for Canada, provinces and territories, census metropolitan areas and census agglomerations, 2011 and 2006 censuses. Available online: <www.statcan.gc.ca>

Ulanova, N.G. 2000. The effects of windthrow on forests at different spatial scales: A review. Forest Ecology and Management 135:155-167.

Valinger, E., and J. Fridman. 2011. Factors affecting the probability of windthrow at stand level as a result of Gudrun winter storm in southern Sweden. Forest Ecology and Management 262:398-403.

Walker, L.R. 1991. Damage and recovery from Hurricane Hugo in Luquillo Experimental Forest, Puerto Rico. Biotropica 23:379-385.

Weaver, P.L. 1999. Impacts of Hurricane Hugo on the dwarf cloud forest of Puerto Rico's Luquillo Mountains. Caribbean Journal of Science 35:101-111.

Webb, S.L. 1989. Contrasting windstorm damage consequences in two forests, Itasca State Park, Minnesota. Ecology 70:1167-1180.

Wiken, E.B., D. Gauthier, I. Marshall, K. Lawton, and H. Hirvonen. 1996. A Perspective on Canada's Ecosystems. Canandian Council on Ecological Areas Occasional Paper No. 14.

World Meteorological Organization. 2011.Review of the Past Hurricane Season: reports of hurricanes, tropical storms, tropical disturbances and related flooding during 22010 (Submitted by Canada) RA IV Hurricane Committee Thirty-Third Session, Grand Cayman, Cayman Islands 8-12 March 2011 RA IV/HC-XXXIII/Doc. 4.2(2).

Zeng, H., H. Peltola, H. Väisänen, and S. Kellomäki. 2009. The effects of fragmentation on the susceptibility of a boreal forest ecosystem to wind damage. Forest Ecology and Management 25:1165-1173.

Zeng, H., J. Garcia-Gonzalo, H. Peltola, and S. Kellomäki. 2010. The effects of forest structure on the risk of wind damage at a landscape level in a boreal forest ecosystem. Annals of Forest Science 67:111p1-111p8.

Zimmerman, J.K., E.M. Everham III, R.B. Waide, D.J. Lodge, C.M. Taylor, and N.V.L. Brokaw. 1994. Responses of tree species to hurricane winds in subtropical wet forest in Puerto Rico: Implications for tropical tree life histories. Journal of Ecology 82:911-922. 
Yolanda F. Wiersma (corresponding author)

Department of Biology

Memorial University

St. John's, Newfoundland, A1B 3X9, Canada

ywiersma@mun.ca

Troy L. Davis

Department of Biology

Memorial University

St. John's, Newfoundland, AlB 3X9, Canada

Elizabeth C. Eberendu

Department of Biology

Memorial University

St. John's, Newfoundland, AlB 3X9, Canada

Ian Gidge

Department of Biology

Memorial University

St. John's, Newfoundland, A1B 3X9, Canada

Maria Jewison

Department of Biology

Memorial University

St. John's, Newfoundland, AlB 3X9, Canada

Hiliary C. Martin

Department of Biology

Memorial University

St. John's, Newfoundland, A1B 3X9, Canada

Kaylah C. Parsons

Department of Biology

Memorial University

St. John's, Newfoundland, A1B 3X9, Canada

Heidi Patterson

Department of Biology

Memorial University

St. John's, Newfoundland, A1B 3X9, Canada

Ashley Quirke

Department of Biology

Memorial University

St. John's, Newfoundland, A1B 3X9, Canada
Résumé. L'ouragan Igor était de catégorie 1 lorsqu'il s'est abattu sur l'île de Terre-Neuve au Canada en causant des dommages majeurs. Les ouragans sont peu fréquents dans les latitudes plus septentrionales et les espèces boréales ne sont pas adaptées face aux vents puissants des ouragans. De plus, la majorité des dommages sont survenus dans la zone urbaine de la ville de Saint-Jean où de nombreux arbres non indigènes sont présents. Cette recherche a permis de vérifier quels étaient les attributs des arbres (i.e. hauteur, DHP, défilement, espèce, âge ou distance avec l'arbre voisin) qui pouvaient avoir eu une influence sur la chute ou non de l'arbre. Les auteurs de l'étude ont échantillonné 70 arbres et on découvert que le DHP constituait une variable significative de prédiction de la chute d'un arbre (bris ou déracinement). Les conifères n'étaient pas plus ni moins sujets à tomber que les arbres feuillus, tout comme les espèces indigènes versus les espèces introduites. Ces résultats suggèrent que pour l'écosystème boréal urbain, il n'existe pas d'espèce préférentielle à planter stratégiquement qui permettrait de minimiser le risque de chute d'un arbre face à des vents de force majeure. De ce fait, pour minimiser les risques de dommages aux infrastructures humaines construites dans des régions où les ouragans sont rares, la meilleure stratégie serait d'éviter d'avoir des arbres à grand déploiement à proximité de ces infrastructures.

Zusammenfassung. Als der Wirbelsturm Igor die Küste von Neufundland, Kanada, passierte und Schaden in höchstem Ausmaß verursachte, war er als ein Wirbelsturm Kategorie 1 charakterisiert. Wirbelstürme sind in den nördlichen Breiten ungewöhnlich und die borealen Baumarten sind nicht an solche Windkräfte angepasst. Nochmehr Schaden entstand in der urbanen Gegend von St. John, einer Stadt, wo auch viele nicht-heimische Arten vorkommen. Diese Forschung testete, $o b$ es Attribute bei den Bäumen (z. B. Höhe, Brusthöhendurchmesser, Schlankheit, Baumart, Alter oder Distanz zum nächsten Baum) gibt, die möglicherweise einen Einfluss darauf hatten, ob der Baum fiel oder stehen blieb. Die Autoren dieser Studie wählten 70 Bäume aus und fanden, dass der Brusthöhendurchmesser eine signifikante Größe für die Vorhersehbarkeit eines Baumversagens (Bruch oder Entwurzelung) ist. Koniferen waren nicht mehr oder weniger sturmgefährdet als Laubbäume und auch einheimische Baumarten waren nicht mehr oder weniger gefährdet als nicht-einheimische Baumarten. Diese Ergebnisse zeigen, dass es für ein boreales, urbanes Ökosystem keine besonders geeigneten Baumarten gibt, deren bevorzugte Pflanzung das Wurfrisiko bei größeren Sturmereignissen minimiert. Daher wird empfohlen, zur Minimierung des Sturmschadensrisikos an der baulichen Infrastruktur in generell sturmarmen Regionen aus strategischen Gründen auf die Pflanzung von größeren Baumarten in der Nähe von Gebäuden zu verzichten.

Resumen. El huracán Igor era de categoría 1 cuando pasó por la Isla de Newfoundland, Canadá, causando daño extensivo. Los huracanes son excepcionales en estas latitudes del norte, y las especies boreales no están adaptadas a los fuertes vientos de estos huracanes. Sin embargo, mucho del daño fue en el área urbana de la ciudad de St. John's, donde hay también numerosos árboles no nativos. Esta investigación probó cuáles fueron los atributos de los árboles (diámetro a la altura del pecho, altura, esbeltez, especie, edad, o distancia al árbol más cercano) que pudieron haber influido para que al árbol cayera o continuase en pie. Los autores del estudio muestrearon 70 árboles y encontraron que el diámetro a la altura del pecho (DAP) fue un indicador significativo de la caída del árbol (quebrados o desenraizados). Las coníferas no fueron más o menos susceptibles que los árboles deciduos; los árboles nativos tampoco fueron más o menos susceptibles a los daños por los vientos que los no nativos. Estos resultados sugieren que para un ecosistema urbano boreal no hay especies disponibles que pudiesen ser plantadas estratégicamente para minimizar el riesgo de que el árbol caiga en un evento mayor de vientos. Por tanto, para minimizar el daño por tormentas a infraestructuras construidas por humanos en regiones donde los huracanes son raros, la mejor estrategia debería ser evitar tener grandes árboles localizados en las proximidades a las infraestructuras. 